JOURNAL OF PUBLIC HEALTH FOR TROPICAL AND COASTAL REGION (JPHTCR)

Journal homepage: http:/ejournal2.undip.ac.id/index.php/jphtr/index

ISSN : 2597-4378

\title{
Determinants of Treatment Adherence among Patients with Severe Mental Disorders at the Kedungmundu Primary Health Center in Semarang City
}

\author{
Deviani Saskia Putria*, Ayun Sriatmi a, Eka Yunila Fatmasaria \\ aPublic Health Faculty, Diponegoro University, Semarang, Indonesia \\ ${ }^{*}$ Corresponding Author. Email: devianisaskia27@gmail.com
}

\section{Abstract}

Background: Treatment adherence among patients with severe mental disorders is needed to avoid dropouts, relapses, and shackling. Kedungmundu Primary Health Center in Semarang City is known to have a low treatment adherence to patients with severe mental disorders. This study aimed to determine the factors associated with treatment adherence among patients with severe mental disorders.

Methods: A quantitative study with a cross-sectional approach. The samples were 73 patients with severe mental disorders at the Kedungmundu Primary Health Center. Data were collected using questionnaires and analyzed using frequency distribution analysis and Spearman Rank Correlation Test.

Results: The results indicated that knowledge $(p=0,000 ; r=0,715)$, attitudes $(p=0,000 ; r=0,839)$, family support ( $p=0,000 ; r=0,427)$, assessment of health workers $(p=0,000 ; r=0,456)$, and the need for health services $(p=0,000 ; r=0,716)$ have a positive correlation with treatment adherence among severe mental disorders patients.

Conclusion: Kedungmundu Primary Health Center is suggested to provide psychoeducation to patients and families, improve the implementation of mental health programs, and empower mental health cadres.

Keywords: Treatment Adherence, Severe Mental Disorders, Primary Health Center 
Background

Mental disorders accounted for the highest proportion of DALYs (Disability Adjusted Life Years) in the Global Burden of Disease study ${ }^{1}$ and one of the largest global economic burden. ${ }^{2}$ Mental disorders are classified into two major categories, namely mental-emotional disorders, including depression and anxiety, and severe mental disorders, including schizophrenia and psychosis. ${ }^{3}$

The prevalence of severe mental disorders in Indonesia has increased significantly every year. In 2018, the number of people with severe mental disorders in Indonesia reached 450 thousand. $84.9 \%$ of them have received medical treatment, but only $48.9 \%$ are adhering to the treatment. ${ }^{3}$

Most people with severe mental disorders recover well and able to live independently with appropriate ongoing treatment and support. During the treatment, they need adherence to avoid drop-outs, relapses, and shackling. It includes adherence to routine checks and therapy to health services and medication adherence. ${ }^{4}$ One of the government's efforts to address mental health problems in Indonesia is the integration of mental health services in primary health care.

The Kedungmundu Primary Health Center (PHC) is one of the health centers with the third-highest number of severe mental disorders in Semarang City in 2018. It's known that treatment adherence to severe mental disorders at Kedungmundu PHC is still low. In 2018-2019, they experienced an increase in cases of severe mental illness from 59 to 73 patients. Some of the patients were former patients who did not continue the treatment, then they experienced a relapse and went back to the treatment.

The purpose of this study was to determine the factors associated with treatment adherence among patients with severe mental disorders at Kedungmundu Primary Health Center in Semarang City.

\section{Methods}

This research was conducted from May to September 2020 in the working area of the Kedungmundu Primary Health Center, Semarang City. This is a quantitative study using a cross-sectional study approach. The independent variables in this study include knowledge, attitudes, family support, assessment of health services, assessment of health workers, and the need for health services. The dependent variable is treatment adherence among patients with severe mental disorders at Kedungmundu PHC.

The population in this study were all patients with severe mental disorders at the Kedungmundu Primary Health Center in Semarang City in 2019. The samples were taken using the total population sampling technique, in which all subjects from the population became the study sample so that the study samples are 73 patients with severe mental disorders.

Data were collected through interviews using a questionnaire and analyzed using frequency distribution analysis and Spearman Rank Correlation Test.

\section{Results and Discussion}

Table 1 shows the characteristics of the respondents. Most of the respondents are male $(61.6 \%)$. The largest percentage of respondents is in the age range of 3645 years $(27.4 \%)$. Most of the respondents have a low educational background $(52.0 \%)$ and not working (64.4\%). 
Table 2 shows that the variables associated with treatment adherence among patients with severe mental disorders at the Kedungmundu Primary Health Center in Semarang City are knowledge ( $p$-value $=0,000)$, attitude $(p$-value $=0,000)$, family support $(p-$ value $=0,000)$, assessment of health workers ( $p$-value $=0,000)$, and the need for health services ( $p$-value = 0,000 ). Meanwhile, the variable that is not associated is an assessment of health services ( $p$-value $=0.973$ ).

\begin{tabular}{|c|c|c|}
\hline \multirow{2}{*}{$\begin{array}{c}\text { Respondent } \\
\text { Characteristics }\end{array}$} & \multicolumn{2}{|c|}{ Total } \\
\hline & $f$ & $\%$ \\
\hline \multicolumn{3}{|l|}{ Sex } \\
\hline Male & 45 & 61,6 \\
\hline Female & 28 & 38,4 \\
\hline \multicolumn{3}{|l|}{ Age } \\
\hline $\begin{array}{l}\text { Late adolescence } \\
(17-25)\end{array}$ & 4 & 5,5 \\
\hline $\begin{array}{l}\text { Early adulthood (26 } \\
-35 \text { ) }\end{array}$ & 17 & 23,3 \\
\hline $\begin{array}{l}\text { Late adulthood ( } 36 \\
-45)\end{array}$ & 20 & 27,4 \\
\hline $\begin{array}{l}\text { Pre-elderly (46 - } \\
55)\end{array}$ & 15 & 20,5 \\
\hline $\begin{array}{l}\text { Late elderly (56 - } \\
65)\end{array}$ & 11 & 15,1 \\
\hline Old age (>65) & 6 & 8,2 \\
\hline \multicolumn{3}{|l|}{ Education } \\
\hline Not school & 5 & 6,8 \\
\hline Elementary school & 12 & 16,4 \\
\hline Middle school & 21 & 28,8 \\
\hline High school & 28 & 38,4 \\
\hline College & 7 & 9,6 \\
\hline \multicolumn{3}{|l|}{ Job status } \\
\hline Not working & 47 & 64,4 \\
\hline Working & 26 & 35,6 \\
\hline
\end{tabular}

Table 1. Respondent Characteristics

\section{Knowledge}

Respondents with high knowledge had a higher percentage (53.4\%) compared to respondents with a lack of knowledge (46.6\%). The result of the Spearman Rank correlation test shows that there is a relationship between knowledge and treatment adherence among patients with severe mental disorders with a $p$-value of 0.000 and a correlation value of 0.715 (strong correlation).

Knowledge of a disease is a significant predictor of adherence and non-adherence. Patients with a lack of knowledge will lead to needless treatment and non-adherence. Patients with a lack of knowledge will lead to needless treatment and non-adherence treatment. ${ }^{5}$ It can be caused by a lack of health education and information about severe mental disorders to patients and their families, and lack of a role of health workers in utilizing routine control time for health education.

A person's knowledge can be influenced by the level of formal education he has. In this study, most of the respondents had a low educational background (52.0\%). A person who has a higher level of education generally has better knowledge and insight so that it is easier to receive information and can overcome his health problems. $^{6}$ Knowledge can also be influenced by the health education provided by health workers. Health workers who do not maximize the provision of mental health education to patients and their families, especially during patient visits to health services, tend to have patients with low knowledge. $^{7}$ 


\begin{tabular}{|c|c|c|c|c|c|c|c|c|}
\hline \multirow{3}{*}{ Variables } & \multicolumn{4}{|c|}{ Treatment Adherence } & \multicolumn{2}{|c|}{ Amount } & \multirow{3}{*}{$\begin{array}{c}\mathrm{p}- \\
\text { value }\end{array}$} & \multirow{3}{*}{$\begin{array}{l}\text { r value } \\
\text { (rho) }\end{array}$} \\
\hline & \multicolumn{2}{|c|}{$\begin{array}{c}\text { Less } \\
\text { obedient }\end{array}$} & \multicolumn{2}{|c|}{ Obedient } & \multirow{2}{*}{$\mathbf{f}$} & \multirow{2}{*}{$\%$} & & \\
\hline & $f$ & $\%$ & $f$ & $\%$ & & & & \\
\hline \multicolumn{9}{|l|}{ Knowledge } \\
\hline Low & 28 & 82,4 & 6 & 17,6 & 34 & 46,6 & 0,000 & 0,715 \\
\hline High & 8 & 20,5 & 31 & 79,5 & 39 & 53,4 & & \\
\hline \multicolumn{9}{|l|}{ Attitude } \\
\hline Not good & 30 & 90,9 & 3 & 9,1 & 33 & 45,2 & 0,000 & 0,839 \\
\hline Good & 6 & 15,0 & 34 & 85,0 & 40 & 54,8 & & \\
\hline \multicolumn{9}{|l|}{ Family support } \\
\hline Less supportive & 16 & 57,1 & 12 & 42,9 & 28 & 38,4 & 0,000 & 0,427 \\
\hline Supportive & 20 & 44,4 & 25 & 55,6 & 45 & 61,6 & & \\
\hline \multicolumn{9}{|l|}{$\begin{array}{l}\text { Assessment of } \\
\text { Health Services }\end{array}$} \\
\hline Not good & 13 & 41,9 & 18 & 58,1 & 31 & 42,5 & 0,973 & $-0,004$ \\
\hline Good & 23 & 54,8 & 19 & 45,2 & 42 & 57,5 & & \\
\hline \multicolumn{9}{|l|}{$\begin{array}{l}\text { Assessment of } \\
\text { Health Workers }\end{array}$} \\
\hline Not good & 19 & 65,5 & 10 & 34,5 & 29 & 39,7 & 0,000 & 0,456 \\
\hline Good & 17 & 38,6 & 27 & 61,4 & 44 & 60,3 & & \\
\hline \multicolumn{9}{|l|}{$\begin{array}{l}\text { The Need for } \\
\text { Health Services }\end{array}$} \\
\hline Low & 28 & 80,0 & 7 & 20,0 & 35 & 47,9 & 0,000 & 0,716 \\
\hline High & 8 & 21,1 & 30 & 78,9 & 38 & 52,1 & & \\
\hline
\end{tabular}

${ }^{*}$ Significancy with $p$-value $<0,05$

Table 2. Frequency Distribution of Relationship between Variables

\section{Attitude}

Respondents with good attitudes had a higher percentage $(54.8 \%)$ compared to respondents with poor attitudes $(45.2 \%)$. The result of the Spearman Rank correlation test shows that there is a relationship between attitudes and treatment adherence among patients with severe mental disorders with a $p$-value of 0.000 and a correlation value of 0.839 (very strong correlation).

Attitude is one of the factors that can influence a person's behavior. ${ }^{8}$ The attitude in this study is the reaction or response of the respondent in response to severe mental disorders, which includes the treatment of patients with severe mental disorders and the patient's treatment of adherence.

Previous studies have shown that patient's attitude towards treatment has an important role in treatment adherence. ${ }^{9,10}$ Study shows that patients who have had adverse experiences with drugs taken during treatment have a more negative attitude towards treatment. ${ }^{11} 65.7 \%$ of respondents in this study agreed that taking drugs regularly can cause side effects or dependence, this attitude can be an influence on treatment adherence by patients with severe mental disorders at Kedungmundu Primary Health Center. 


\section{Family Support}

Respondents who received good support from their families had a higher percentage (61.6\%) compared to respondents who received less support from their families (38.4\%). The result of the Spearman Rank correlation test shows that there is a relationship between family support and treatment adherence among patients with severe mental disorders with a p-value of 0.000 and a correlation value of 0.427 (moderate correlation).

Family support is the attitude and actions of the family towards sick family members in providing directions to adhere to the treatment program. Family support includes sources of funding, access to health centers, orders, invitations, advice, providing information, and support for recovery. Based on the respondent's answers, it stated that there are still families who did not support the patient, including not knowing the patient's treatment schedule and taking medication, not seeking and providing information about the treatment, not knowing the patient's symptoms, and telling patients to stop the treatment when the patient's condition looks better.

Family as a patient-caregiver at home has a big role and responsibility in the patient's treatment process. During the process, families tend to have a high burden, including feelings of guilt, anxiety, tension, ignorance in handling patients, and the financial impact of the family. An effort that can be made to improve the ability of families to provide support and obtain solutions to problems in dealing with patients is to facilitate the formation of a Self Help Group (SHG). This group consists of families of patients with severe mental disorders who can help each other share knowledge, reminding, and supports. ${ }^{12}$ Families need to realize that severe mental illness is a long-term disorder, which means that patients need the treatment and support that is comprehensive and sustainable in the long term. ${ }^{13}$

\section{Assessment of Health Workers}

Respondents who had a positive assessment of health workers had a higher percentage (60.3\%) compared to respondents who had a negative assessment of health workers (39.7\%). The result of the Spearman Rank correlation test shows that there is a relationship between the assessment of health workers and treatment adherence among patients with severe mental disorders with a $p$-value of 0.000 and a correlation value of 0.456 (moderate correlation).

The results are in line with the research conducted by Adriana et al. regarding Medication Adherence and Satisfaction with Treatment and Guidance by The Health Team in a Mental Health Service. This study stated that high satisfaction with health workers can be an influenced factor with patients' treatment adherence. Most of the patients expressed satisfaction with the treatment provided, included the effectiveness of the drug and the information provided. ${ }^{14}$

A person's assessment of health workers can make someone return to using a health service or not. ${ }^{15}$ Assessment of health workers in providing health services, including examination of patients, providing information about treatment and drug consumption, and emotional support to patients. Some respondents who had a bad assessment of health workers, stated that there were still health workers who did not offer health education or information about severe mental disorders, less friendly, did not give support to patients, did not answer patient questions, and did not respond to patient's complaint. 
Kedungmundu Primary Health Center needs to consider improving the competence of health workers and empowering health cadres by providing mental health training in early detection of mental disorders, handling mental disorders patients, and patient care during home visits.

\section{The Need for Health Services}

Respondents who had a high need for health services had a higher percentage (52.1\%) compared to respondents who had a low need for health services $(47.9 \%)$. The results of the Spearman Rank correlation test show that there is a relationship between the need for health services and treatment adherence among patients with severe mental disorders with a $p$-value of 0.000 and a correlation value of 0.716 (strong correlation).

The results are in line with research conducted by Bhushan et al. regarding the Evaluation of Treatment Adherence in Outpatients with Schizophrenia. It explained that one of the primary reasons a person does not adhere is because they perceive treatment and medication as unnecessary. ${ }^{5}$

Patients who do not adhere are likely to feel that their treatment is unhelpful, useless, ineffective, or unnecessary. Meanwhile, patients who adherent and agreed with treatment tend to be able to describe their conditions, seek help, and agree with the benefits of treatment. However, in some cases, after the acute episode, some patients discontinued the treatment because they felt they were well and no longer needed the treatment. ${ }^{16}$ The need for health services is related to a person's health condition, a person who feels that they are vulnerable to certain health conditions tends to take action to prevent undesirable conditions. ${ }^{15}$

\section{Conclusion}

Kedungmundu Primary Health Center is one of the health centers with low treatment adherence among patients with severe mental disorders. Based on the findings, factors that have a significant relationship with treatment adherence among severe mental disorders patients are knowledge, attitudes, family support, assessment of health workers, and the need for health services. It is recommended for the Kedungmundu Primary Health Center to conduct psychoeducation to patients and their families, especially during patient visits, focusing on the consequences of non-adherence, the side effects of some drugs, identifying the symptoms of patients who experience relapse, and the importance of family support. Besides, forming a Self Help Group (SHG) consists of families of severe mental disorders at the Kedungmundu Primary Health Center, where they can help each other share knowledge, reminding, and supports. Then, increasing the competence of health workers and empowering health cadres by providing mental health training in early detection of mental disorders, handling mental disorders patients, and patient care during home visits

\section{References}

1. Kohn R, Saxena S, Levav I, Saraceno B. The treatment gap in mental health care. Bulletin of the World Health Organization. 2004;82(11):858-66.

2. World Health Organization. The world health report 2001 - Mental Health: New Understanding, New Hope. Geneva: WHO Library Cataloguing in Publication Data; 2001.

3. Kementerian Kesehatan Republik Indonesia. Riset Kesehatan Dasar Tahun 2018. 
4. Niven N. Psikologi Kesehatan. Jakarta: EGC; 2002.

5. Chaudhari B, Saldanha D, Kadiani A, Shahani R. Evaluation of treatment adherence in outpatients with schizophrenia. Industrial Psychiatry Journal [Internet]. 2017 [cited 2020 Aug 25];26(2):215. Available from: /pmc/articles/PMC6058450/?report $=$ abstract

6. Dinas Kesehatan Provinsi Jawa Tengah. Profil Kesehatan Provinsi Jawa Tengah Tahun 2018 [Internet]. 2018 [cited 2020 Sep 24]. Available from:

http://dinkesjatengprov.go.id/v2018/ dokumen/profil_2018/mobile/index. html

7. Videbeck L. Buku Ajar Keperawatan Jiwa. EGC; 2008.

8. Azwar S. Sikap Manusia, Teori, dan Pengukurannya. Yogyakarta: PT Pustaka Pelajar; 2011.

9. Elen Konis K. Faktor-Faktor yang Mempengaruhi Kepatuhan Pasien Skizofrenia Melakukan Kontrol Rutin terhadap Kesehatan Jiwa di Poliklinik RSJD Dr. Amino Gondohutomo Semarang. 2012;

10. Ganesan S, Selvaraj N, Dass K, Jayabalan N, Rajamohammad A, Anandan I. Assessment of drug attitude, medication adherence and quality of life among psychiatric patients in South Indian population: a cross sectional study. International Journal of Basic \& Clinical Pharmacology [Internet]. $2019 \mathrm{Dec}$ 24 [cited 2020 Sep 24];|(1):61-7. Available from: www.ijbcp.com

11. Uhlmann C, Kaehler J, Harris MSH, Unser J, Arolt V, Lencer R. Negative impact of self-stigmatization on attitude toward medication adherence in patients with psychosis. Journal of Psychiatric Practice [Internet]. 2014 [cited 2020 Sep 24];20(5):405-10. Available from: https://pubmed.ncbi.nlm.nih 